\title{
Attitudes Gaps to Jewish Out-Group and Arab In-Group as an Expression of the Self-Identity of the Arab Minority in Israel
}

\author{
Hujierat Mussa \\ The Academic Arab College Of Education ,Haifa-Israel \\ hujierat@gmail.com
}

\begin{abstract}
The objective of this study is to examine the practice of members of an in-group giving preference to the in-group rather than the out-group in any society, thereby providing its members with status, prestige and a positive social identity. This study examines the gap in the emotional attitude of the in-group and the out-group. The out-group in this study is the Jewish majority and the in-group is the Arab minority in Israel. This gap has been researched in large part, in research in laboratory conditions. Research has been done less on actual groups. The purpose of this study is to examine the degree of emotional identification of the Arab minority with the suffering and sorrow related to an unfortunate tragic event that occurs to another member of their group and to one that occurs to a member of the Jewish out-group. It is also to find how the attitude gaps relate to the traditionalism level of the in-group and to the region where the subjects live. To begin, a questionnaire was composed that included details about events that provoke feelings of grief and sadness. Subjects were asked in the pilot study to respond emotionally to these events. The hypothesis was that the Arab minority would identify emotionally with their group and less with the Jewish out-group and that a gap would be found that is related to the residential region and society's level of traditionalism. The findings show a bias of emotional attitude to the Arab side. The gaps that were discovered in the attitude to both groups were related to the society's level of traditionalism and partially to the residential region.
\end{abstract}

Keywords: Emotional attitude, Arab Minority, Jewish Majority, Identity, Social Identity, In-group, Out-group

\section{Introduction and Literature}

Social Identity theory corresponds to relationships within the group (Hogg, 2006) and, therefore, there is an assumption that it is necessary to define the group in order to clarify the concept of group membership, group belongingness concept, type of groups (in-group and out-group) and the social categories. Zavalloni defined the "group" concept as "a concept that includes several elements which at various levels identify the individual. This applies to social categories such as age, gender, or nationality, but it can also refer to social roles such as members of a particular profession or political position." (Deschamps, 1982). Deschamps claims that this definition is not enough and, therefore, relies on Tajfil's assertion in 1972 that the group definition (nationality, race, etc.) becomes significant only in relation to other groups. (Tajfel \& Turner, 2004). He believes that the group becomes a group only when it is perceived as having general characteristics or a common destiny only because of the existence of other groups in the vicinity. Thus, he emphasized the differences between the groups and that these differences are only important when they are perceived and valued by members of the group.

Tajfil's remarks are a refining of the boundaries between the groups which is legitimate and acceptable for any group. The boundaries are a perception of the difference from others and the foundation of this difference. Tajfil claims that "social groups should build a clear distinction from other groups in order to provide their members with a positive social identity. (Hogg \& Abrams, 1998; Abrams \& Hogg, 1999) However, when referring to social groups we get Deschamps contention that there are groups within an interdependence system and the relationships between them are not only co-existent but existing side by side. This kind of relationship is consistent with Shaw's definition in 1976 that a group is "two or more people having an interaction whereby each one influences the others and is influenced by them." (Deschamps, 1982). The social group concept received importance in the field of social psychology which differentiates between large social categories and small groups. This concept of classical social psychology organizes groups and explains group behavior in terms of interaction between friends. (Hogg \& Vaughan, 2002; Baron \& Byrne, 2003) Turner referred to the idea of the social group in cognitive terms and defined the group as "two or more people with a general common social identification or who perceive themselves as members in the same social category." (Turner, 1982) But in 1989, Turner and 
Oakes defined the psychological group concept as "a collection of people sharing a general recognition of themselves or perceiving themselves as members in the same social category." (Robinson, 1996:30)

Members of a certain group always tend to define themselves as "a group" operating in a symbiotic manner, developing a social structure and with positive mutual emotional ties. Thus, they become a group to which belonging to become an emotional element and this element is strengthened by a social cohesion model. (Tajfel \& Turner, 2004) The group to which an individual belongs is of great significance to him because it affects his personal identity and planning his life. Any group that people feel that they belong to determines their thoughts regarding who they are, what kind of people they are and how they communicate with each other. Group belongingness is psychological and not just knowledge about the group features. Belonging is related to social identity in the sense that perception of someone or defining his identity is made up of descriptions of self in terms of the defined characteristics of the social groups to which he belongs. Indeed, an individual's knowledge of belonging to a group is not enough for him to feel that he is part of it. Therefore, the individual should be deeply aware of his belonging to any group in order to be able to identify with it. This leads to the fact that a psychological group does not exist if the "individuals" do not identify with it.

According to Tajili's definition, group membership is mainly central for social identity which is as he states, "The individual's recognition of his membership in certain social groups and the emotional and moral importance of this membership." (Tajfil, 1982: 292) This membership is a central part of the self which can provide many positive things such as the feeling of group belongingness, self-esteem and the sense of belonging to something that is greater than the personal self. The membership instills greater achievements than the individual himself. The sense of membership that connects the individual to others is the basis for cooperation in social life. (Abrams \& Hogg, 2001; Smith \& Mackie, 1995) Perception of people in terms of members of social groups leads to the tendency to emphasize the similar things that exist within the group. This causes them to refine and emphasize the different things that distinguish any group from any other group. (Robinson, 1996) This idea is social categorization based on the social category which is a collection of friends with at least a general stance common to them.

Others will refer to the social category as a group with an extended scope. That category exists when certain members identify or are identified as part of a certain group. A particular category can become a psychological group when it becomes another group with a belief that will define its existence. Then unity will be able to develop common activity. (Xenia, 1996) Belonging to a social category means that the individual devotes himself to this belonging compared to others who do not belong to the same category or to those who associate themselves with another category. The individual perception of this belonging to a specific category as opposed to belonging to any other category is a process called social categorization.

Members of a social category not only associate themselves with a social category but identify with it because of a human need and tendency to achieve positive social identity. The individual will identify with the category that will provide him with positive self-esteem. (Hornsey \& Jetten, 2004; Xenia, 1996; Tuner, Hogg, Oakes, Reicher \& Wetherell, 1987) Since the positive aspects of social identity are comparative in nature and are derived from the systemic comparison between social groups, the groups will make sure to distinguish themselves positively from other groups and compare themselves with those groups. The inter-group comparison will emphasize the structure and strengthening of the characteristics valued by the in-group. (Robinson, 1996) Emphasizing the difference in the category together with the need for positive diagnosis creates a situation where the in-group prefers other members of the in-group rather than those of the out-group. Turner's self-categorization theory in 1987 was to present the group's design and preference for the in-group. According to this perspective, the personal and social identities are different in that they represent different levels of abstraction of selfcategorization (Hogg, 2006). The sub-system of information enters the separate entity category so that the differences within this category are fewer than the differences between them and others. The individual eliminates the personal qualities of his self-perception and is perceived as a representative of the in-group with characteristics that differentiate it from the out-group. According to the self-esteem theory, depersonalization of one's self-concept lays the foundation for the group phenomena such as ethnocentrism, cooperation, and conformism with the group customs. (Tyler \& Blader, 2001; Tropp \& Wright, 2004; Tuner, Hogg, Oakes, Reicher \& Wetherell, 1987). 
Social categorization is decisively related to "self". Classification of other people must include implications to ourselves which expels the categorical connections between the self and others. People tend to categorize others on the basis of similarities and differences from the self. People perceive others as members of the same category (the in-group) or members in a different category (the out-group). We categorize ourselves like we categorize objects, experiences and other people (Spears, 2001). The selfcategorization process creates the emphasis of the similarities between the self and others (members of the in-group) and the differences between the self and others (members of the out-group) (Postmes \& Jetten, 2006; Schubert \& Otten, 2002). Emphasizing the similarities between the self to the members of the in-group is the social identification of the individual with the group. The complex identification of the individual with the group members becomes the social identity. (Hogg, 2003; Ellemers, Spears \& Doosje, 2002). Group membership is a psychological condition. This perception creates shared social representation for members of the same group. Individual relationships will be with members of his group (the in-group) and members of the out-group and both affect his perception of "who he is, what kind of person he is and his relations with others." (Gaertner \& Dovidio, 2000; Hogg \& Abrams, 1998; Hogg \& Terry, 2000; Deschamps, 1982; Babad, Birnbaum \& Benne, 1983).

Theorists' presumption of social identity is that the differences between the out-group and in-group stem from the social assessment processes. (Brewer \& Norman, 1996; Ellemers, Spears \& Doosje, 2002) There is a universal tendency in humans to prefer the in-group over the out-group. (Tamir \& Nadler, 2007) This approach presents the social categories and the relationships between which are the basis for the heterogeneous social structure that is complex and constantly changing. This occurs from changes in the categories themselves due to the impact of economic power and historical relations and also due to changing relationships between the groups. The dominant group dictates the nature of society as a whole, and its component groups and the relationships between them. The categories provide the individual and the society with the need for social order, structural, consistency, etc. (Tajfel \& Turner, 1979). The individual derives his identity from these categories (self-meaning and self-perception) through the psychological processes which are responsible for the group's behavior. These provide one or more identities because of the individual's affiliation to more than one group. (Brewer \& Roccas, 2002; Nick \& Steve, 1996; Penner, Dovidio, Piliavin \& Schroeder, 2005) The comparison between the in-group and the out-group and the preference of in-group members for the in-group over that of the out-group provides members of the in-group with status, prestige and positive social identity. Therefore, social categories and membership in them are linked to negative and positive values. Thus, the social identity will be positive or negative. (Ellemers, Spears \& Doosje, 2002; Gonnet, 2000).

Turner and Oakes proved that the distinction between the groups based on social categorization is linked to the self-esteem of the members of different social categories. The individual's need for positive selfesteem is an indicator of behavior within the group. Therefore, the individual will see the virtues of his group for himself. However, for the out-group he will perceive the negative characteristics of their group. (Murk, 2006; Turner, 1982) If so, this need for positive self-esteem regulates the relations between and within the groups because the individuals do not compare themselves with the group but they compare themselves to members of the out-group. (Penner, Dovidio, Piliavin \& Schroeder, 2005; Gonnet, 2000).

This study examines the gap in the emotional attitude of members of the in-group to the in-group and the out-group. The out-group in this study is the Jewish majority and the in-group is the Arab minority in Israel. This Arab minority is indeed the minority group in the State of Israel and naturally identifies emotionally with the Palestinians (the Palestinian nation) and the Arab group (the Arab world). This gap has been examined in studies in lab conditions and less on actual groups. It has not previously been studied according to the attitude of the Arab minority group in Israel toward the Jewish citizens of Israel. As mentioned, studies show that there is a preference of the in-group to view the in-group as being better than the out-group. Tajfil claims that this preference is intended to raise the self-esteem of the in-group. (Tajfil, 1981). The attitude test was conducted in the period after the Gaza War (according to the Palestinians) or Oferet Yezuka (Operation Cast Lead according to the Israelis). This war disrupted the social relations between the two groups, mainly as a result of the attack on Gaza. This war was violent and difficult for the residents of the Strip, in particular, and the Palestinians, in general. It is possible that the Israeli Defense Force's (IDF's) violent and painful behavior in the Gaza Strip projected on the entire Jewish population. 
The first purpose of the study is to examine the degree of emotional identification of the Arab minority, members of the in-group, with the suffering and sorrow of the unfortunate tragic event that occurs to another member of their group. Also, the purpose is to examine their degree of emotional identification with the suffering and sorrow of a member of the Jewish out-group. Another purpose of the study is to find how the attitude gaps of the subjects to events about the in-group and out-group related to the ingroup's level of traditionalism and how they are related to the region where the subjects live. Chosen are sadness and grief provoking events that allegedly should arouse similar humane feelings regardless of the relationship between the two groups. These are based on the assumption raised in Tajfil's laboratory studies. The contention is that there would be a gap in the emotional attitude toward similar events that are happening to both groups.

\section{Study Hypothesis}

The hypothesis is that the Arab minority will identify emotionally with their group (the in-group) and less with the Jewish out-group. A gap will be found between the emotional expressions of the in-group about episodes defining the in-group and those expressions about episodes which define the out-group. The attitude gap of the Arab minority to the Arab in-group and Jewish out-group will be related to the region where they live and to society's level of traditionalism.

\section{Methods}

Study Population: The study subjects are high school students of the Arab minority in Israel. Arab citizens of Israel live within the 1948 borders in three large demographic concentrations - the Galilee (the northern part of Israel), the HaMeshulash (the Triangle) and the Negev (The Negev Desert, the southern part of Israel) - and they constitute about $19 \%$ of the overall population including residents of East Jerusalem (3.5\%). From a religious point of view, there is a Muslim sub-group in this population which constitutes a majority (12\%), a Christian sub-group (2.1\%) and a Druze sub-group (1.6\%). (Israel Central Bureau of Statistics, 2009) This study focuses on examining the emotional attitude gap of the Muslim majority to the in-group and out-group. Members of the Muslim majority in this population are tested just because they constitute the majority. Amongst them are urban, rural and Bedouin students.

The Sample: The sample includes 475 students, 10,11 and 12 grades, 14-17 years old adolescents. Choice of the sample population is based on the assumption that adolescence is a decisive stage of an individual's life when physical, intellectual and social changes occur. The adolescent is occupied with many questions at this stage. The important question is how he perceives himself and how others see him in relation to his integration into the adult group. (Erikson, 1968) The decision in these issues is a personal and collective identity formation process of the individual which is, according to Erikson, a positive result of this stage. That being the case, adolescence is important and decisive in identity formation. This is especially true of the ethnic identity among adolescents from ethnic minorities. Because the main component of collective social identity is the emotional attitude gap to the in-group and outgroup, (Hujierat, 2008) and also because of the importance of the identity issue, in general, in the adolescent stage, it is justified to examine this gap among adolescents. However, caution should be taken in inclusion of the findings from this age group in the general population.

Study Method: A special original questionnaire was prepared to examine the attitude gap of the subjects to events in the Arab in-group and the Jewish out-group. For questionnaire composing, sadness and grief provoking the events that occurred to a member of one of the groups or to the entire group were chosen. The selected events were arranged simultaneously so that one event related to the in-group (the Arab minority) and the other to the out-group (the Jewish majority). The questionnaire was distributed to a small sample in the pilot study to check its validity and reliability. The study questionnaire was distributed to 475 adolescent subjects from various high schools in the Arab sector with representation in the three residential blocks: the Galilee (the northern part of Israel), HaMeshulash (the Triangle) and the Negev (The Negev desert, the southern part of Israel). The schools chosen for the sample had teachers, family or friends known personally by the researcher. The teachers were instructed about the distribution and how to answer questions that would be asked. The teachers distributed the questionnaires to the students during a regular class and all present completed the questionnaires. The questionnaires were submitted anonymously and the students were promised that they would not be used elsewhere, especially in the school. 
At the end of the class, the questionnaires were collected by the teachers and sent to the researcher and the data was entered. Seven questionnaires were not completed correctly and were not included in the sample. Questions with missing values received the average score. The number of missing values was less than $10 \%$. The data was processed on SPSS software and various variance analysis tests were made including Chi square test and different correlations.

Research Tools: To examine the emotional attitude gap for the social in-group and out-group, a questionnaire was composed that includes details about events that provoke feelings of grief and sadness. After a pilot study in which the first items were examined, six were left which constituted the final study questionnaire. Every item is an incident that occurred to a member of one of the groups or to the entire group. Three incidents are related to the Arab minority in Israel and three to the Jewish majority. The events selected are:

- A Jewish Tel Aviv boy was seriously injured in a bicycle accident and died as a result of his injuries.

- Electrocution of an Arab boy from Shfar-am (an Arabic town) who died later.

- Palestinians fired rockets at Israel killing two Israelis and injuring more than twenty Jews.

- IDF (Israel Defense Forces) shelled targets in Gaza killing nine schoolchildren.

- Deaths of three Jewish family members from Netanya (a Jewish city) due to a fire in their home.

- Deaths of an Arab family from Kfar Kassem (an Arab village) in a motor vehicle accident.

The subjects are asked to express their feelings towards each incident. The answers are rated on a scale from 1 to 5: 1 - very sad, 2 - sad, 3 - no special feeling, 4 - happy, 5 - very happy. Scores range from 6 (all answer 1 - very sad) and 30 (all answer 5 - very happy). The score that was calculated is the average of the answers of each subject and the attitude gap for both groups was also calculated (Ma average answers relating to the Arab minority group in Israel with minuend $\mathrm{Mj}$ average answers relating to the Jewish majority group). The questionnaire was scanned by two independent researchers to validate content and their comments were taken into account. As mentioned, the questionnaire was distributed to 475 subjects.

\section{Results and Discussion}

In order to examine the attitude gap between the attitudes of study group to the in-group and to the outgroup, a series of different analyses were conducted. Double differences were tested by comparing the ratio of the in-group to the out-group in similar pairs of questions. The findings related to both the first and second events have shown that most of the participants (86.9\%) in their answers expressed a tendency to identify with the in-group.

Table no. 1 shows that the subjects expressed deep sorrow for the death of the Arab child in that $63.9 \%$ expressed a sad or very sad feeling and only about 5.4\% expressed the same feeling toward the death of the Jewish child. $25.5 \%$ of the subjects referred to the death of the Jewish child with indifference compared with only about $13 \%$ that referred to the death of the Arab child with indifference. It is possible to explain this finding as a solution to the Jewish-Arab conflict. The Arab minority wanted to express their negative feelings toward events that occur to Jews although the attitude toward the given event is allegedly humanitarian and not political. In the same spirit, $69.1 \%$ of the subjects expressed a sense of joy toward the death of the Jewish child compared to $12.4 \%$ who expressed the same feeling to the death of the Arab child. It is strange that $12.4 \%$ of the subjects also expressed a happy feeling toward the death of an Arab child - a member of the in-group. This finding is not consistent with the rest of the findings and there is no explanation for this.

Examination of the differences between the average attitudes toward both groups (in and out) was conducted by using a $\mathrm{T}$ test. It was found that there is a significant difference between the average attitude towards the in-group and average attitude towards the out-group $(\mathrm{T}=25.16, \mathrm{df}=627, \mathrm{p}<0.000)$. Average subject answers to the event relating to the Arab child were 2.42 that is an expression to a "sad" answer. This is compared to their average answers regarding the death of the Jewish child which was 4.02 which corresponds with "joy". In other words the gap between them was 1.6. 
Table 1: Distribution of the subjects answers by the kind of the events (Frequencies) $(\mathrm{N}=468)$

\begin{tabular}{|c|c|c|c|c|c|c|}
\hline The event/The feeling & Very sad & Sad & $\begin{array}{l}\text { No special } \\
\text { feeling }\end{array}$ & Hарру & Very Happy & Mean \\
\hline A Jewish Tel Aviv boy was seriously & 16 & 10 & 119 & 147 & 176 & 4.02 \\
\hline $\begin{array}{l}\text { injured in a bicycle accident and died } \\
\text { as a result of his injuries. }\end{array}$ & 3.4 & 2 & 25.5 & 31.4 & 37.7 & \\
\hline Electrocution of an Arab boy from & 108 & 154 & 145 & 18 & 40 & 2.42 \\
\hline Shfaram who died later & 31 & 32.9 & 13 & 3.8 & 8.6 & \\
\hline
\end{tabular}

$\mathrm{T}=25.162 \mathrm{df}=627 \mathrm{p}<0.000$

The findings relating to the third event - "Palestinians fired rockets at Israel killing two Israelis and injuring more than twenty Jews" - and the fourth - "IDF shelled targets in Gaza killing nine school children" - showed that most of the subjects $(91.7 \%, \mathrm{~N}=468)$ expressed in their answers a tendency to identify with the in-group as well.

Table no. 2 shows that the subjects expressed deep sorrow and identification with the suffering of the Arabs at the deaths of their dear ones in that $92.8 \%$ expressed sad and very sad feelings and only about $12.7 \%$ expressed the same feeling toward the deaths of two Jews and injury of more than twenty others from rocket fire at Israel. $61.3 \%$ of the subjects responded with indifference to the deaths and injuries of the Jews compared to only about $4.7 \%$ who expressed indifference to the deaths of the Arab students in Gaza. 26\% of the participants expressed a sense of joy toward the deaths and injuries of the Jews compared to only about $2.5 \%$ who expressed the same feeling at the deaths of the Arab students in Gaza.

Regarding the deaths and injuries of the Jews, the average answers of the subjects was $3.48 \%$. This is an expression of indifference compared to their average answers regarding the killing of the Arab students in Gaza by the IDF shelling in Gaza Strip that is 1.83 which is "sad". In comparison to the event of the death of the Jewish boy, the subjects expressed less malicious joy at the event of the rocket fire. The explanation for this finding may be that some of this population $(\mathrm{N}=468)$ did not want to express their real feelings toward this event because the death was caused by hostile external elements which is seen in Israel as an act of terrorism so that any expression of joy would be interpreted as support of terrorism.

Table 2: Distribution of the subjects answers by the kind of the events $(\mathrm{N}=468)$

\begin{tabular}{lccccccc}
\hline The event/The feeling & Very Sad & sad & $\begin{array}{c}\text { No special } \\
\text { feeling }\end{array}$ & Happy & Very Happy & Mean \\
\hline Palestinians fired rockets at Israel killing two & 30 & 29 & 285 & 16 & 106 & 3.48 \\
Israelis and injuring more than twenty Jews. & 6.5 & 6.2 & 61.3 & 3.4 & 22.6 & \\
IDF shelled targets in Gaza killing nine & 393 & 41 & 22 & 6 & 6 & 1.83 \\
school children. & 84 & 8.8 & 4.7 & 1.3 & 1.2 & \\
\hline
\end{tabular}

$\mathrm{T}=31.668 \quad \mathrm{df}=626 \mathrm{p}<0.000$

Here as well, the attitude gap to both events showed bias to the Arab side meaning less sorrow to the Jewish suffering and more emotional identification with the Arab suffering and sorrow $(\mathrm{Mj}-\mathrm{Ma}=3.48$ $1.83=1.65)$.

The findings related to the fifth event - "the deaths of three Jewish family members from Netanya (a Jewish city) due to a fire in their home" - and the sixth event - "the deaths of Arab family from Kfar Kassem (an Arab Village) in a motor vehicle accident" - also showed that most of the subjects $193.9 \%$, $\mathrm{N}=468$ ) expressed in their answers a tendency to identify with the in-group. Table no. 3 shows the subjects expressed deep sorrow and identification with the Arabs suffering at the deaths of their dear ones. 93.9\% expressed a sad and very sad feeling at the deaths of the Arab family members from Kfar Kassem whereas only about $3.27 \%$ expressed the same feeling at the deaths of the Jewish family from Netanya. $7.5 \%$ of the subjects showed a sense of indifference at the deaths of the Jewish family from Netanaya compared to about $5.3 \%$ who showed a sense of indifference to the deaths of the Arab family from Kfar Kassem. Despite the low percentage, it can be seen that the subject have more a sense of indifference to the deaths of the Jewish family than a sense of indifference to the deaths of the Arab family. 59.8\% of the participants expressed a sense of joy at the deaths of the Jewish family from Netanya compared to $0.8 \%$ who expressed a sense of joy at the deaths of the Arab family from Kfar Kassem. Average subject answers to the event relating to the deaths of the Arab family from Kfar Kassem are 1.95 
that corresponds to the answer "sad". In comparison, the average answers regarding the deaths of the Jewish family from Netanya are 3.09 corresponding to "joy".

Table 3: Distribution of the subjects answers by the kind of the events $(N=468)$

\begin{tabular}{lcccccc} 
The event/ The feeling & Very sad & Sad & $\begin{array}{c}\text { No special } \\
\text { feeling }\end{array}$ & Happy & $\begin{array}{c}\text { Very } \\
\text { Happy }\end{array}$ & Mean \\
\hline Deaths of three Jewish family members & 90 & 63 & 35 & 99 & 181 & 3.09 \\
from Netanya due to a fire in their home. & 19.3 & 13.4 & 7.5 & 21.2 & 38.6 & \\
Deaths of Arab family from Kfar Kassem & 336 & 103 & 25 & 2 & 2 & 1.91 \\
in a motor vehicle accident. & 71.9 & 22 & 5.3 & 0.4 & 0.4 & \\
\hline
\end{tabular}

$\mathrm{T}=4.828 \mathrm{df}=633 \mathrm{p}<0.000$

The attitude gap to both these events also showed a bias to the Arab side meaning, as mentioned, less sorrow to the Jewish suffering and more emotional identification with the Arab suffering and sorrow (Mj - Ma $=3.09-1.91=1.18$ ). In comparing the responses of both sexes, relatively small insignificant differences were found and, therefore, do not deserve any reference.

Examining the distribution of the findings - relating to the "death of the Jewish boy" and the "Arab boy" according to residential area, it was found that among the subjects in the Galilee $66.2 \%$ expressed sorrow at the death of the Arab boy compared to only $6.7 \%$ who expressed sorrow at the death of the Jewish boy from Tel Aviv. $45.7 \%$ of the subjects from the HaMeshulash (the Triangle) expressed sorrow at the death of the Arab boy compared to only $4.1 \%$ who expressed sorrow at the death of the Jewish boy. In the Negev, 46.9\% expressed sorrow at the death of an Arab boy compared to 4.6\% who expressed sorrow at the death of the Jewish boy. The findings show a difference between the subjects in the Galilee and the rest of the subjects from the HaMeshulash (the Triangle) and the Negev. In the Galilee, more sorrow is shown at the death of the Arab boy and also towards the death of the Jewish boy. It can be assumed that the attitude is more humanitarian beyond the national affiliation of the deceased individual. The data in the HaMeshulash (the Triangle) and Negev show more discrimination from the in-group against the outgroup.

Examining the distribution of the findings relating to the other four events, no significant differences were found. Regarding the six events, (see table no. 4) the gap between the subjects' attitude to the ingroup and the out-group was tested and no significant differences were found among residential areas.

Table 4: Means Distribution of Attitudes Gaps to the Events that related to in-group and out-group

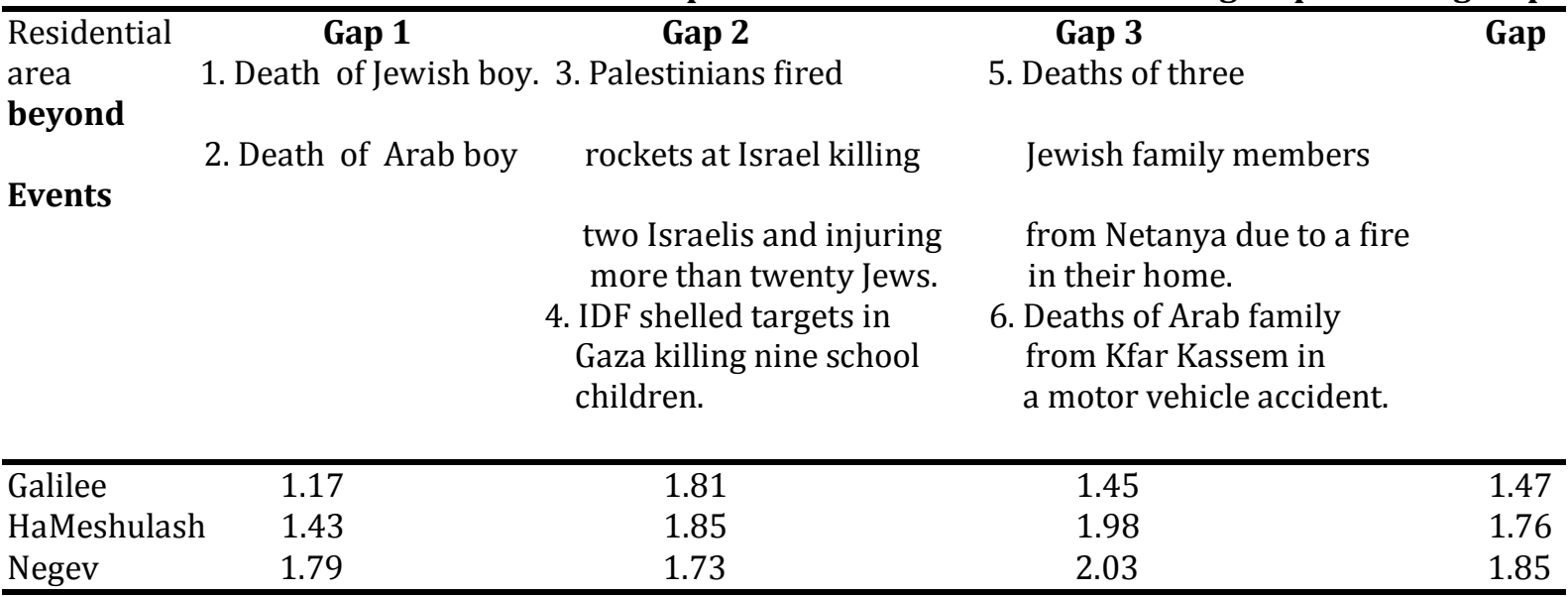

To examine the effect of event type on the subjects' attitude to both groups, two tragic events were taken which from an humane point of view should arouse feelings of sadness and sorrow. Also, two happy events were selected which from a humane point of view should arouse a feeling of joy. As mentioned, in the first two events - "the death of a Jewish boy" and the "death of an Arab boy" - there was a significant gap $(\mathrm{T}=25.16, \mathrm{df}=627, \mathrm{p}<0.00)$ in the subjects' attitude to both events. In both happy events "advancement of Ahi Nazareth (an Arabic football team) to the Israeli premier league" - compared to "Beitar Jerusalem (a Jewish football team from Jerusalem) wins State Cup in 2009 after defeating 
defending champion Maccabi Haifa (A Jewish football team from Haifa city)" - there was a gap but very small. The findings showed that the gap is related to the type of event that was used. Unlike previous tragic events, the subjects expressed a sense of joy to sporting events related to Jews but more so when the event is related to the in-group.

Attitude Gap to the In-Group and Out-Group and Society's Level of Traditionalism: Another purpose of the study was to find how the attitude gaps of the subjects to events related to the in-group and outgroup are related to the level of traditionalism of the in-group. Table no. 5 shows the distribution of attitude gaps to the in-group and out-group according to the groups' level of traditionalism.

Table 5: Distribution of Attitudes Gaps by society's level of Traditionalism ( $N=468)$ (Mean and standard of deviation)

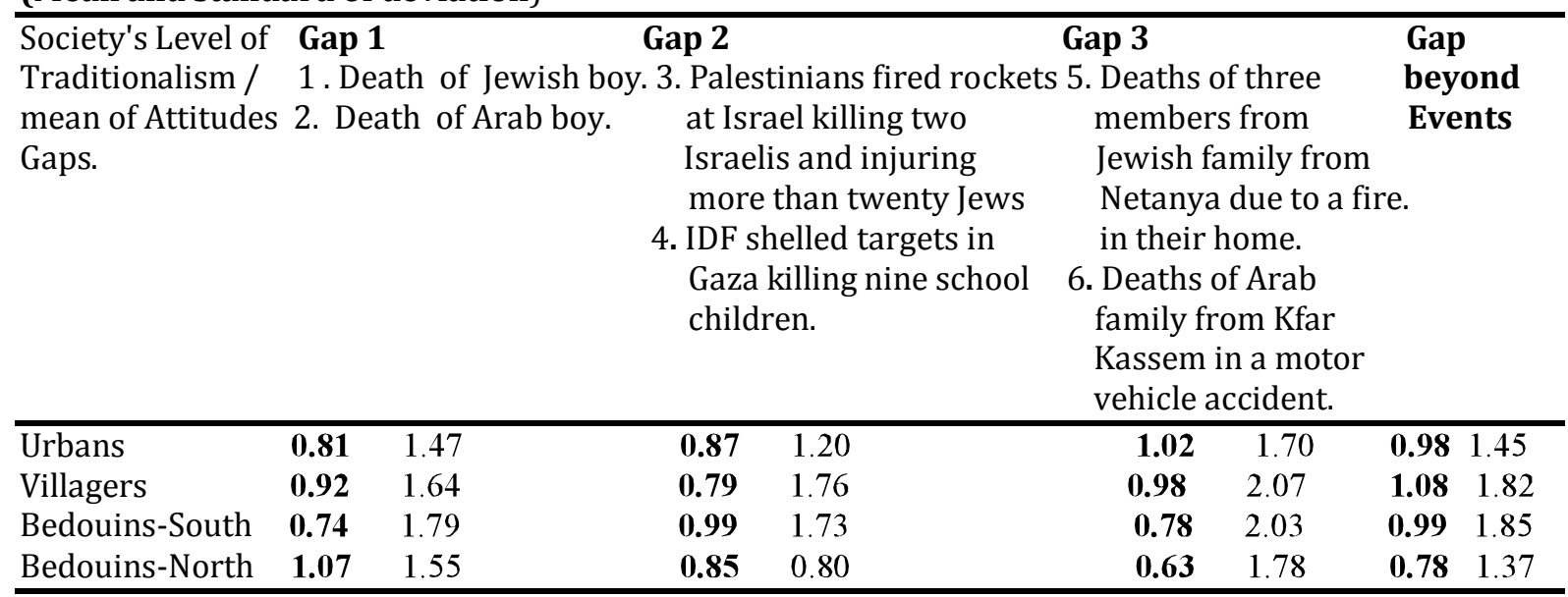

Findings of a variance analysis test of the averages of the attitude gaps between the Jewish out-group and the in-group according to society's level of traditionalism was $(\mathrm{F}=33.87, \mathrm{df}=3, \mathrm{p}>0.000)$. The smallest gap was with the Bedouin in the northern part of Israel which is similar to the gap of the urban subjects. This is probably because they are young people who, unlike the other groups, undergo field training, Gadna (youth battalions) programs, visit military sites and they are prepared for recruitment to the IDF. Therefore, they are more likely to identify with the Jewish majority group, the out-group.

The largest gap is found in the Bedouins in the southern part of Israel and in the rural population. This is probably because of their very difficult living condition and, therefore, they see in their attitude a sort of protest against the dominant majority group. Society's lifestyle affects the subjects' attitudes to events that occur to the in-group compared to events that occur to the out-group. In terms of society's level of traditionalism, the urban population is closer to the majority group and, therefore, the attitude gap was smaller.

\section{Conclusion}

Previous studies have noted the universal tendency of humans who belong to an in-group to prefer the members of this in-group over the members of the out-group. This is how the desire to examine this gap in the Arab minority group in Israel arose. Comparisons of the two groups show that the practice of the members of the in-group preferring their own group provides members of that group with status, prestige and positive social identity. Another study determined the attitude gap to both groups as an important component of identity. The test was conducted in the period after the Gaza War (according to Palestinians) or "Oferet Yezuka" (Operation Cast Lead according to the Israelis) which disrupted the social relations between the two groups, mainly as a result of the attack on Gaza which was violent and difficult for the residents of the Strip, in particular, and the Palestinians, in general.

The inquiry was about the degree of emotional identification of the Arab minority, members of the ingroup, with the suffering and sorrow of the unfortunate tragic event happening to another member in the group compared to their degree of emotional identification with the suffering and sorrow of a member of the Jewish out-group. The query was also to examine how the attitude gaps of the subjects to events related to the in-group and out-group are related to the group's level of traditionalism and to the region 
where the subjects live. The hypothesis is that the Arab minority will identify emotionally with their group and less with the Jewish out-group. And, also, the hypothesis is that a gap will be found within the Arab minority between their emotional expressions towards the in-group and their emotional expressions towards the out-group. This gap is related to both the residential region and the society's level of traditionalism. A study questionnaire was prepared, distributed, and data collected. In order to examine the attitude gap of the study group to the in-group and out-group, a series of variance analysis tests were formulated. The findings showed an impressive confirmation of the study hypothesis in that most of the participants $(86.9 \%, \mathrm{~N}=468)$ expressed in their answers a tendency for identification with the in-group. The attitude gap to the six events showed bias to the Arab side which means, as mentioned, less sorrow for the Jewish suffering and more emotional identification with the Arab suffering and sorrow.

Thus, these finding are validations to the previous research done on the in-group and the out-group. As mentioned, the members of the in-group (in previous researches and especially in Tajfel's researches on laboratory groups) prefer their group. In this study, the new finding is that there is a relationship between the identification with the in-group and the residential area of the subjects. The findings here show that most of the participants expressed in their answers a tendency for identification with the ingroup. This tendency was related to the residential area of the participants but only in some of the events. Society's lifestyle affects the subjects' attitude to events occurring to the in-group and to the outgroup. From the point of view of society's level of traditionalism, the urban population is closer to the majority group and, therefore, apparently the attitude gap is smaller. Thus, any future study or relevant discussion must deal with the following two points:

- Attitudes of the out-group and the in-group are an integral part of the identity of the subjects.

- The attitudes of the subjects of the two groups are not constant. They are related to the residential area and society's level of traditionalism. Their attitudes are also related to the period when the study occurred and to the general relationship between the two groups, especially the political one.

\section{References:}

Abrams, D. \& Hogg, M. (1999). Social identity and social cognition. Oxford: Blackwell.

Abrams, D. \& Hogg, M. (2001). Collective identity: Group membership and self-conception. In M. Hogg \& R. Tindale (Eds.), Blackwell handbook of social psychology: Group processes (pp. 425-460). Oxford: Blackwell. Brewer, M. \& Norman, M. (1996). Intergroup Relations. Buckingham: Open University Press.

Brewer, M. \& Roccas, S. (2002). Social Identity Complexity. Personality and Social Psychology Review. 6, 88-106.

Baron, R. \& Byrne, D. (2003). Social Psychology. Boston: Allyn and Bacon.

Babad, E., Birnbaum, M. \& Benne K. (1983). The Social Self: Group influence on Personal Identity. London: Sage Publications, Beverly Hill.

Deschamps, J. (1982). Social identity and relations of power between groups. In H. Tajfil, Social Identity and Intergroup relations (85-97). Cambridge: Cambridge University Press.

Ellemers, N., Spears, R., \& Doosje, B. (2002). Self and social identity. Annual Review of Psychology, 53, 161186.

Erikson, E. (1968). Identity, youth and crisis. New York: Norton \& Company.

Gaertner, S. \& Dovidio, J. (2000). Reducing intergroup bias: The common in-group identity model. Philadelphia: Psychology Press.

Gonnet, R. (2000). Relationships between Groups. Social Psychology. 8, 137-213.

Hogg, M. \& Abrams, D. (1998). Social Identifications: A social psychology of intergroup relations and group processes. London: Routledge.

Hogg, M. \& Terry, D. (2000). Social identity and self-categorization processes in organizational contexts. Academy of Management Review, 25, 121-140.

Hogg, M. \& Vaughan, G. (2002). Social Psychology. London: Prentice Hall.

Hogg, M. (2003). Social identity. In M. Leary \& J. Tangney (Eds.), Handbook of self and identity (462-480). New York: Guilford.

Hogg, M. (2006). Social identity theory. In P. J. Burke (Ed.), Contemporary social psychological theories (111-136). Palo Alto: Stanford University Press.

Hornsey, M. \& Jetten, J. (2004). The individual within the group: Balancing the need to belong with the need to be different. Personality and Social Psychology Review, 8, 248-264. 
Hujierat, M. (2008). Collective Identity of the Arab Minority in Israel: Complex Identify and Self-Esteem. Kfar Qara: Alhuda Press.

Israel Annual Statistics, Israel Central Bureau of Statistics, 2009.

Mruk, C. (2006). Self-Esteem research, theory, and practice: Toward a positive psychology of self-esteem. New York: Springer.

Nick, H. \& Steve, R. (1996). The Construction of Social Categories and Processes of Social Change: Arguing about National Identities, In G. Breakwell, Changing European Identities (pp. 69-95). Oxford: Butterworth-Heinemann.

Postmes, T. \& Jetten, J. (2006). Individuality and the group: Advances in social identity. London: Sage Publications Inc.

Penner, L., Dovidio, J., Piliavin, J., \& Schroeder, D. (2005). Prosocial behavior: Multilevel perspectives. Annual Review of Psychology, 56, 365-392.

Robinson, P. (ed.). (1996). Social Groups and Identities: developing the legacy of Henri Tajfel. Oxford: Butterworth Heinemann.

Smith, E. \& Mackie, M. (1995). Social Psychology. New York: Worth Publishers.

Spears, R. (2001). The interaction between the individual and the collective self: Self-categorization in context. In C. Sedikides \& M. Brewer (Eds). Individual self, relational self, and collective self: Partners, opponents or strangers? (pp. 171-198). Philadelphia: The Psychology Press.

Schubert, T. \& Otten, S. (2002). Overlap of self, in-group and out-group: Pictorial measurement of self categorization. Self and Identity, 4, 353-376.

Tropp, L. \& Wright, S. (2004). In-group Identification as the Inclusion of In-group in the Self. Personality and social Psychology Bulletin. 27, 585-600.

Tamir, Y. \& Nadler, A. (2007). The role of personality in social identity: Effects of field-dependence and context on reaction to threat to group distinctiveness. Journal of Personality, 75(5), 927-954.

Tajfil, H. \& Turner, J. (1979). An Integrative Theory of intergroup conflict. In G. Austin, \& S. Worchel. The social psychology of intergroup relations (pp. 305-315). Monterey, CA: Books/Cole.

Tajfil, H. (1981). Human groups and social categories: Studies in social psychology. Cambridge: Cambridge University Press.

Tajfil, H. (1982). Social Identity and Intergroup Relations. Cambridge: Cambridge University Press.

Tajfel, H. \& Turner, J. (2004). The social identity theory of intergroup behavior. In J. Sidanius \& J. Jost (Eds.), Political psychology: Key readings (276-293). New York: Psychology Press.

Turner, J. (1982). Towards a cognitive redefinition of social group, In H. Tajfil, Social Identity and Intergroup Relations (15-41). Cambridge: Cambridge University Press.

Tuner, J., Hogg, M., Oakes, J., Reicher, D. \& Wetherell, S. (1987). Rediscovering the Social Group: A SelfCategorization theory. Oxford: Blackwell.

Tyler, T. \& Blader, S. (2001). Identity and prosocial behavior in groups. Group processes and intergroup relations. 4, 207-226.

Xenia, C. (1996). How Group Membership is formed: Self Categorization or Group Beliefs? The Construction of a European Identity in France and Greece. In G. Breakwell. Changing European Identities (297-315). London: Methuen. 